\title{
EL «STABAT MATER» GLOSADO Y TRADUCIDO POR SOR MARÍA GERTRUDIS DE LA CRUZ HORE A FINES DEL SIGLO XVIII
}

\author{
POR \\ FRÉDÉRIQUE MORAND \\ Doctora en Estudios Hispánicos, Université Paris VIII
}

\section{RESUMEN}

El artículo da a conocer esta olvidada creación y sus distintas ediciones, el mayor éxito literario de María Gertrudis Hore, religiosa Concepcionista Calzada en Cádiz. Se descubre, por vez primera, la superchería de la astuta erudita, a la vez que la interesante fusión literaria realizada entre prosa, verso y música sacra al estrechar hábilmente dos tiempos litúrgicos habitualmente distantes. En este escrito propiamente inmaculista, el uso continuo del referente femenino destaca por su novedad.

PALABRAS ClAVE: Stabat Mater, monja, superchería, fusión literaria, Cádiz, siglo XVIII.

\begin{abstract}
The essay gives us new information about the most famous Gertrudis Hore's creation, profess in the Concepcionist convent of Santa María in Cádiz, and her several editions. For the first time, we find out the fraud literary and copy of this shrewd poetess, however, at the same time, a really interesting melting between prose, poem and holy music on tightening liturgical period normally distant. In this writing, typical of Virgin literature, a continually using of feminine references do innovation form's to this text.
\end{abstract}

KEY WORDS: Stabat Mater, nun, fraud literary, melting, Cádiz, $18^{\text {th }}$ century. 


\section{A) PRESENTACiÓN}

\section{La autora}

Antes de discurrir y reflexionar sobre el «Stabat Mater Dolorosa», cuya autoría original se atribuye al monje italiano Jacopone da Todi (1236-h.1306), situamos a la autora de esta creación original en las postrimerías del Setecientos tanto en su ciudad como en su comunidad religiosa. Sor María Gertrudis de la Cruz Hore (1742-1801), dama de la alta burguesía gaditana, fue mujer culta e inquieta, la única hija de una familia de comerciantes irlandeses de renombre antes de ser monja. Poetisa desde su juventud, casada con el nuevo socio de su padre, Gertrudis Hore entró en el monasterio gaditano de Santa María del Arrabal para siempre tras dieciséis años de vida matrimonial. Tenía treinta y cinco años a primero de junio de 1778 cuando ingresó, con la licencia de su esposo Esteban Fleming, para formar parte de este cenobio cuya advocación era, y sigue siendo, el de la Concepción. Única monja casada de la congregación, y con una formación de calidad (traducía latín ${ }^{1}$ e italiano, tenía conocimientos del idioma galo, de Astronomía, Historia, Geografía, Matemática, era aficionada a la Música, etc.), la Hija del Sol, llamada así por sus contemporáneos por su belleza y su erudición, fue secretaria durante dos trienios en la década de 1790 y «acompañante de médico», aunque nunca llegó a formar parte del discretorio, 0 sea, del grupo en el que se discutía los asuntos de la comunidad. Esta mujer, medio seglar (35 años), medio monja (23), murió de madrugada en su celda, el martes 9 de agosto de 1801 con 58 años, en pleno periodo de fiebre amarilla ${ }^{2}$.

\section{Las distintas publicaciones}

Ahora bien, cuando se editó el texto del presente objeto de nuestro estudio, ni la autora, ni tampoco su impresor anotaron fecha alguna en la dicha publicación ${ }^{3}$. Sin embargo, el lugar de la edición, la imprenta de Josef Niel situada en

\footnotetext{
1 La Novena presentada a la censura eclesiástica en diciembre de 1777 se termina por una antífona y una oración en latín lo que permite afirmar que lo escribía antes de entrar en clausura. Novena al Santo Cristo de la Esperanza que se venera en el Convento de Santa María de la ciudad de Cádiz, compuesta por una Persona devota de esta Venerable Imagen. D. Manuel Espinosa de los Monteros Impresor de la Real Marina, Cádiz, 1778. (48 pp.) Según las informaciones dadas por N. M. Cambiaso, su primer biógrafo, María Gertrudis Hore «sabía muy bien el latín». N. M. CAMBIASO, Memorias para la biografía y para la bibliografía de la isla de Cádiz, II, Madrid, 1830, pp. 72-73.

2 Frédérique MoRAND, «Sor María Gertrudis de la Cruz Hore (1742-1801): últimos hallazgos sobre la epidemia que asoló Cádiz», en Trocadero, 16 (2004), 103-123.

3 Traducción del Hymno Stabat Mater Glosado, que hace la R. M. Doña María Gertrudis de la Cruz Hore, Religiosa del Convento de Santa María de Cádiz. Con Licencia: En Cádiz, por Don Josef Niel, Calle San Francisco. 13 páginas en 8. $^{\circ}$, inclusa la portada. No hay fecha. Según las informaciones
} 
la Calle San Francisco, permitía precisar algo más. Interesándome en los editores gaditanos, me di cuenta de que éste se instaló en dicha calle en 1787, lo que reducía de algunos años el momento de la creación, sin lugar a duda tardía, del Stabat Mater traducido y glosado por la erudita monja ${ }^{4}$.

Este texto fue el más conocido y el más reconocido de todas sus composiciones religiosas (Novena, Quinario, Deprecación a María Santísima...): primero, fue publicado en Cádiz por la autora, en Barcelona se publicaron extractos a cargo de Fray Beato Diego y, de nuevo fue editado en la ciudad barcelonesa en 1863 en la revista el Año Cristiano del Padre Jean Croisset y, por fin, se publicó en Sevilla en 1921 en La voz de San Antonio ${ }^{5}$. En cuanto a la publicación de Fray Diego, sabiendo que pasó por el monasterio de Santa María a predicar en 1798, conociendo la presencia de un bonito retrato suyo en el coro bajo, así como la conservación por la actual comunidad del crucifijo con el que predicando recorría las calles de Cádiz (según decía siempre Madre Esperanza), es de suponer que el dicho Stabat Mater salió a la luz en Cádiz entre 1787 y 1798.

\section{La crítica franciscana}

Tras consultar la antología franciscana de referencia de Samuel Eijan, me di cuenta de que Sor María Gertrudis de la Cruz Hore irrumpía sola en el seno de la comunidad poética franciscana en medio de un auditorio masculino ${ }^{6}$. Era la única poetisa de la segunda mitad del siglo XVIII reconocida como erudita digna de representar la lírica seráfica española en aquella época:

dadas por M. SERRANO y SANZ, Apuntes para una biblioteca de Escritoras Españolas desde el año 1401 al 1833, Madrid, 1975, p. 532. El original podría estar todavía en una fundación privada de Nueva York: «Cruz y Hore» en The Hispanic society of America, Catalogue of the Library, Vol. 3 (CatDia), Massachusetts, 1962.

${ }^{4}$ José Cebrián García, D. Luis de Luque y Leyva y sus imprentas, contribución al estudio de la tipografía gaditana del siglo XVIII, Caja de Ahorros de Jerez de la Frontera, 1985, pp. 22-23.

5 El texto del «Stabat» al que tuve acceso está en la Biblioteca Pontificia de la Universidad de Comillas; es la reedición del «Stabat»de María Gertrudis Hore en Año Cristiano, II, Madrid 1863, pp. 278-287. La publicación del Beato Diego la localicé en la Biblioteca Nacional de Madrid: en el lomo de este libro en 4' sólo está escrito: Beato Diego J. de Cádiz pero al abrirlo se descubre la autora: «Stabat Mater glosado: y traducción, que hizo del mismo. La R.M. Doña María Gertrudis de la Cruz y Hore, Religiosa del Convento de Sta. María de Cádiz», Barcelona, s.f. Localicé también en el Archivo del Convento de San Antonio de Sevilla algunos extractos publicados por F. Pedro P. Hernández O.F.M, en La Voz de San Antonio, 26 (1921), 328-331. Aprovecho la publicación para dar las gracias a la comunidad de Franciscanos de Sevilla, cuyo archivo no está abierto al público, y en especial al Padre Hermés Jildo Zamora, monje bibliotecario por sus valiosos consejos, y esta tarde inolvidable. V. Apéndice.

${ }^{6}$ Samuel EIJAN, Nuestros juglares del Señor. La poesía franciscana en España Portugal y América. (Siglos XIII a XIX), Santiago, 1935, p. 371. 
Nuestra ilustre poetisa, al tomar la pluma (...) la mueve con igual soltura y elegancia escribiendo en latín que en castellano. Prueba elocuentísima de ello (...) la Traducción del Himno «Stabat Mater». Dicho Stabat Mater Glosado, es, en efecto, traducción muy feliz de la glosa al Stabat, hecha en latín por ella misma. No sólo sigue allí la idea del Benito Jacopone, sino que le imita en la métrica y en el estilo. (...) armoniza en su pluma la fluidez jugosa del lenguaje, las delicadezas de la observación psicológica y las ternuras del sentimiento $(\ldots)^{7}$.

Ningún crítico literario en la actualidad, por no interesarse nunca en la poesía religiosa de Sor María de la Cruz, tenía constancia de estas reediciones, ni tampoco de los ecos de su éxito como escritora franciscana en las últimas décadas del Setecientos. El mejor conocimiento de los frailes, muy probablemente por herencia generacional, de las creaciones religiosas de Sor Gertrudis, no dejaba lugar a duda. Como subrayó el padre Samuel Eijan, ella imitó el poema original del «Stabat» atribuido, aunque se siga cuestionando la autoría, a Jacopone da Todi, siguió la idea del monje franciscano y le imitó en el estilo y la métrica. Exaltó el dolor y la pasión, respaldó la noción de «cultura femenina» desenvolviéndose en el lugar idóneo para defender su posición marianista. Monja concepcionista, cuyo hábito y cerúleo manto recordaba las representaciones pictóricas de la virgen María en la Edad Media, eligió desplazar el cristocentrismo de la «liturgia imperante a favor de un referente femenino» ${ }^{8}$, sin faltar nunca al debido respeto hacia la jerarquía eclesiástica. Si bien es cierto, a finales del siglo XVIII había libertad para hablar de la Virgen María, el tema seguía cargado de valor simbólico y político. María Gertrudis desafió, en cierto modo, el poder masculino tal y como lo hizo en sus orígenes la fundadora de esta original orden femenina al pedir regla propia para sus hermanas ${ }^{9}$.

\section{La polémica sobre la Virgen María}

No podía pasar por alto el largo proceso al que fue sometido el dogma de la Inmaculada Concepción durante siglos: a partir del siglo IV las escrituras em-

${ }^{7}$ Cito en nota de pie de página las reediciones de 1863 y 1921. Ibidem, pp. 404-405.

8 V. El excelente artículo de Ángela MUÑ̃z FERNÁNDEZ, «El monacato como espacio de cultura femenina. A propósito de la Inmaculada Concepción de María y la representación de la sexuación femenina», en Pautas históricas de sociabilidad femenina. Rituales y modelos de representación, Universidad de Cádiz 1999, pp. 71-89. De la misma autora: Acciones e intenciones de mujeres en la vida religiosa de los siglos XV y XVI, Madrid 1995.

${ }_{9}$ Desde su origen la Iglesia prefirió relacionar a estas «nuevas» monjas con alguna orden masculina ya establecida, principalmente los franciscanos y los cistercienses (Beatriz de Silva, la fundadora, vivió cuarenta años en el monasterio cisterciense de Santo Domingo); además, las Concepcionistas como se llaman ahora (O.I.C), conocieron influencias de otras órdenes durante los difíciles momentos de las primeras fundaciones (Benedictinos, Jerónimos). V. Otro excelente estudio. María del Mar GRAÑA CID, Beatriz de Silva (ca. 1426-ca.1491), Madrid, 2005 (93 pp.).

Hispania Sacra, LVIII

118, julio-diciembre 2006, 579-607, ISSN: 0018-215-X 
pezaron a referirse a la Virgen con el título griego de Theotokos (Madre de Dios). El concilio de Éfeso (431), tercer concilio ecuménico de la Iglesia cristiana, lo confirmó de forma solemne poniendo fin a la controversia provocada por el monje Nestorio (fallecido c. 451), el que insistía en que María era madre de Jesús y no de Dios. Sin duda el franciscano Duns Scoto (h. 1266-1308), el «Doctor sutil», fue quien más reveló y exaltó con entusiasmo la opinión de la Concepción Inmaculada. En el siglo XV el Papa Eugenio IV (1431-1447) propuso legitimar el culto a la Virgen María pero la proposición no se adoptó de forma oficial. En el Concilio de Basilea (1431-1449), sesión XXXVI, el Papa examinó esta situación y declaró que la opinión piadosa estaba conforme a las Santas Escrituras y que había de ser adoptada y sostenida por los fieles ${ }^{10}$. La fiesta de la Concepción, llamada por algunos la fiesta de la Santificación, fue de observancia libre hasta el decreto de este concilio. Finalmente, Sixto IV la ordenó por medio de constituciones en los años 1476 y 1483. Pío V, por su constitución de 1570, declaró dejar la libertad a cada uno de tener acerca de ello la opinión que creyese la más piadosa o la más probable. Alejandro VII confirmó las constituciones de Sixto IV por una bula de 8 de diciembre de $1661^{11}$.

Ahora bien, uno de los argumentos utilizados por Sor María de la Cruz Hore para defender el culto a la Santísima Virgen se apoyaba en la proposición defendida por la Universidad de París, en aquel entonces Colegio de Teología y alta autoridad muy respetada: a fines del siglo XVI, el Jesuita Juan Maldonado, habiendo agitado la cuestión de la Concepción Inmaculada de la Virgen, tratándola como un problema, incomodó profundamente a los teólogos de $\mathrm{Pa}$ rís. El rector de la Sorbona dio sus quejas a Pedro de Gondi, obispo de la ciudad, quien se declaró a favor de Maldonado. Este teólogo español, nacido en 1534, había sido acusado de herejía por la universidad por haber enseñado que no era de fe el decir que la Virgen había sido concebida sin pecado. Sin embargo, la facultad de teología consultada por el obispo de París se hallaba dividida al sostener los unos que la opinión de la Inmaculada Concepción era de fe, y los otros considerándola sólo una opinión piadosa ${ }^{12}$. El obispo pronunció sentencia de absolución a favor de Maldonado el día 17 de enero de 1575. El Papa Gregorio XIII (1572-1585) confirmó la sentencia y, desde aquel tiempo, se

10 Josef MuÑoz, Sermón de la concepción Inmaculada de María SS.ma, Madre de dios y señora nuestra predicado en la iglesia del convento de Sta. M. ${ }^{a}$ de esta ciudad de Cádiz el día 12 de diciembre de 1781, asistiendo el Illmo. cabildo Eclesiástico, y el Excmo Ayuntamiento, en cumplimiento del Voto perpetuo hecho en el Año de 1654 cuando con la mayor solemnidad juraron en la misma Iglesia ser constantes defensores de la Pureza Original, Cádiz, 1781, p. 17.

${ }^{11}$ Luís Moreri, El Gran Diccionario Histórico o Miscelánea curiosa de la Historia Sagrada y profana, III (Primera Parte), París 1753, p. 285. Sor Gertrudis poseía en su celda este diccionario (10 volúmenes), pero no se conserva hoy en la Biblioteca conventual.

12 Ibidem, p. 285. 
sostiene comúnmente la opinión de la Concepción Inmaculada, mas no como un punto de $\mathrm{fe}^{13}$.

\section{B) Evolución de un teXto del $\mathrm{s}$. XIII AL Gusto Del $\mathrm{s}$. XVIII}

Tras recordar las grandes líneas acerca de la legitimidad del culto, y en especial la polémica debatida en la Sorbona, consideramos esta composición del «Stabat», creada en el siglo XIII quizás por este monje italiano y su re-creación, mezcla de versos y prosa a finales del Setecientos, por esta monja de velo negro, Sor María de la Cruz Hore.

En primer lugar, acordémonos que la estética del siglo XVIII fue confrontada al problema de la imitación: la imitación que reproducía las apariencias del modelo, copiándolo, y la «imitación ideal» que pretendía superar el modelo. Para Diderot, la «mimesis», cuyo debate inició Platón en sus libros III y X de la República, estaba ligada a una experimentación incesante, presuponía una disociación previa de sus principios para, luego, restaurarlos. Éste era el procedimiento analítico característico de la filosofía de las Luces. Imitar invitaba al recuerdo, reavivaba la memoria, pero no era suficiente, había que pulir, de forma sensible, el contenido espiritual del texto para superar el modelo, ofrecer novedades de interés.

Para Sor Gertrudis, la novedad tuvo una clara voluntad de extensión, apoyo y reconocimiento al culto a la Inmaculada Concepción a finales de la centuria. El texto se adaptaba a las directivas dieciochescas encomendadas por Benedicto XIII (1724-1730) al instituir este Papa una segunda fiesta anual de los Siete Dolores de María Santísima el Viernes de la semana de Pasión (la otra el 15 de septiembre), además de presentar el «Stabat» como himno y secuencia, algo poco presente en la liturgia antes de la promulgación de esta Bula papal. Cabe destacar que el «Stabat Mater» estaba incluido en Misales europeos desde el siglo XV pero que no se introdujo en el Breviario Romano inglés (Roman Breviary and Missal) antes de $1727^{14}$. Por tanto, la imitación en el siglo XVIII de este escrito del siglo XIII ofrecía una nueva relación con el texto modificando el valor, el sentido y la utilización del modelo para adaptarle a las nuevas exigencias del llamado Siglo Ilustrado. Este proceso permitía profundizar en la conciencia histórica y recordaba el lugar ocupado por la Virgen María en la Iglesia, un espacio por el que todavía había que luchar, un espacio que defendió

13 Ibidem, VI, pp. 77-78.

14 El canto de la «secuencia» del «Stabat» fue desde aquel entonces obligatorio. Salvador LóPEZ, El Himno «Stabat Mater Dolorosa» traducido en verso y explicado por la sagrada escritura y SS.PP., Málaga, 1849, pp. 5-7. Silvie MAMY, «Le Stabat Mater au Concert spirituel», en Studi Pergolesiania, III, (1999) 235-250. 
Sor Gertrudis con vehemencia ilustrando sus convicciones con comentarios y reflexiones hechas por eminentes Doctores de la Iglesia a lo largo de la historia.

\section{Estafa literaria}

Al menos eso pensaba antes de dar con el tomo III del Año Cristiano publicado en 1791, obra traducida del francés, añadido con la traducción exacta de las Epístolas, Evangelios, Reflexiones y Meditaciones por Juan Julián Caparrós, capellán del monasterio de religiosas Agustinas de Santa María Magdalena de Madrid.

Sabía, gracias al inventario post mortem conservado en el Archivo conventual, que María Gertrudis estuvo en posesión de una colección no completa del Año Cristiano, esta misma revista en la que localicé la reedición de su traducción y glosa al Stabat, en 1863, más de medio siglo tras la muerte de la poetisa. Pues bien, hace poco, a petición Sor María Luz Suárez, la actual abadesa, me vine a Cádiz para organizar la biblioteca del Monasterio en el que Sor Gertrudis vivió sus últimos veintitrés años. Atenta a los numerosos volúmenes conservados en la Biblioteca, catalogando y hojeando cada obra, volví a dar con trece tomos de la primera edición de Benito Cano de la revista Año Cristiano de 1791, además del tomo I del Suplemento de diciembre de $1793^{15}$.

Si bien es cierto, al consultar ediciones del siglo XIX, había comprobado que la organización del «Stabat Mater» compuesto por Sor Gertrudis era idéntica a la estructura utilizada en estas publicaciones decimonónicas (Reflexiones, Meditaciones, Punto primero, Punto Segundo, Propósitos), hasta hace poco no había tenido la oportunidad de consultar la primera edición en español de finales del siglo XVIII, o sea, cuando Sor Gertrudis publicó, a mi parecer, esta creación. Por otra parte, me di cuenta de que las publicaciones de finales de la centuria estaban compuestas únicamente de textos en prosa, mientras que las del siglo XIX, entrecortaban sus distintas reflexiones con poesías sagradas, tal y como Sor Gertrudis había decidido organizar su creación ya a finales del siglo XVIII. No obstante, cual fue mi sorpresa al consultar más detenidamente el dicho tomo tercero, el que empezaba desde el Domingo de Pasión hasta el de la Pascua de Resurrección: al apartado Viernes de la semana de Pasión descubría, algo aturdida, la glosa al «Stabat» con sus Reflexiones, Meditaciones, Punto primero, Punto segundo, Propósitos ${ }^{16}$, idén-

15 Están los tomos I, II, III, IV y V traducidos del francés (de la obra del Padre Jean Croisset) al castellano por el Doctor don Joaquín Castellot, y los números de febrero, de abril a julio, de octubre a diciembre traducido al castellano por el Padre Joseph Francisco de Isla, catorce tomos en buen estado de conservación.

${ }^{16}$ Año Cristiano o ejercicios devotos para todos los domingos, día de Cuaresma y fiestas móviles del año, III, (1791) 112-120. 
ticos o casi idénticos a los publicados por la Madre Cruz: al leer los puntos primero y segundo de su Meditación «De los Dolores de la Santísima Virgen» no encontré variaciones algunas entre los dos textos, sin embargo, en el punto dos de sus Propósitos pude apreciar, a mi juicio, algunas correcciones hechas por María Gertrudis.

La primera, cuando el autor de la revista dieciochesca animó a sus lectores a rezar hasta el Viernes Santo, el Himno «Stabat Mater Dolorosa»: «Propón hacerlo desde hoy infaltablemente» ${ }^{17}$, escribió éste mientras que Sor Gertrudis tuvo la deferencia de enmendar la incorrección, sustituyéndola por un «sin falta». Algunas líneas más abajo, en el Año Cristiano estaba escrito: «medita un misterio a cada decena del Rosario»; María Gertrudis prefirió decirlo con algo más de precisión cambiando «cada decena» por «cada diez». Éstas eran las únicas diferencias entre las dos publicaciones. Tal vez, ahora, pueda estrechar aún más la publicación de este texto sin fecha entre finales de 1791 y 1798. Sin embargo, más importante que el posible período de publicación, aunque de interés, era el hallazgo de su inesperada actitud literaria.

Mi primer pensamiento fue que María Gertrudis había sencillamente copiado las ocho páginas del texto en prosa de esta publicación madrileña que ella sabía de difícil adquisición, tanto por el escaso número de lectores (aunque tal vez no tanto en Cádiz) como por el precio de estos libros de pasta buena. El erudito gaditano Sebastián Martínez, como Sor Gertrudis en su celda, poseía la revista Año Cristiano del padre Jean Croisset ${ }^{18}$, aunque ella lo tuviera incompleto, tal y como lo descubrí en «su» monasterio. Me parecía difícil pensar que este tercer tomo, que tuve el privilegio de manejar en la mismísima clausura, no fuera el que utilizó la gaditana para componer esta creación cuyo encanto, he de decirlo, acababa de desvanecerse, aunque sólo fuese en parte.

Primero, porque desde la perspectiva dieciochesca la noción de plagio no me parecía tan clara: «era una especie de crimen literario» eso sí, pero para «los pedantes, envidiosos y tontos que perseguían en pleito a los escritores famosos», un simple hurto de pensamientos, según dijo Monsieur Marmontel, aunque se distinguía el timo con más o menos intensidad si fuera el de un autor antiguo o moderno, extranjero o compatriota, muerto o vivo ${ }^{19}$. En este caso, Sor Gertrudis usó el texto de otro, compatriota vivo, sin mencionarlo y poco después de su publicación, es decir que se encontraba en una de las peores situaciones literarias para un amante de las Letras. El silencio y la intención de dar por suyo lo que se ha copiado de otro respondía a la definición de plagio, según

17 Ibidem, 119.

18 A. García-BARQuero GonZález, Libro y cultura burguesa en Cádiz: La biblioteca de Sebastián Martínez, Cádiz, 1988, pp. 45-46 y 49.

19 Diderot y D'AlemBerT, en Encyclopédie ou dictionnaire raisonné des sciences, des arts et des métiers, par une societé de gens de lettres, VIII, (1751-1766), fol. 567. 
Jean-Michel Brutus, erudito veneciano del siglo XVI ${ }^{20}$. Pierre Bayle (16471706), en su Dictionnaire historique et critique (1696), consideraba el plagio como un defecto moral y un auténtico pecado.

Sin embargo, Fontenelle dijo que «una verdad no pertenece al que la encuentra, sino al que la nombra» $\mathrm{y}$, con mayor motivo cuando el pensamiento pertinente del autor, oscurecido por la difícil divulgación de una edición inaccesible para la mayoría de los creyentes, no permitía sacar mayor provecho del discurso de su autor. Sor Gertrudis hizo suyas las palabras de Molière cuando dijo: «Recojo mi bien donde lo encuentro» ${ }^{21}$, como hizo suyas las Reflexiones y Meditaciones del Padre Joaquín Castellot que, probablemente, no hubiesen atravesado los dos últimos siglos para llegar hasta nuestros días si no hubiesen sido recorridas por la astuta monja. Marmontel comparó el derecho en literatura al derecho público, a la propiedad de un terreno cuya función era el cultivo: si el propietario lo abandonaba a su suerte, la sociedad tenía derecho de exigir de él que lo cediera o bien que lo hiciera prosperar. Pues, en literatura, ocurría lo mismo: una idea fecunda era como un bien común que se ofrecía al primero que sabría hacerla brotar, progresar y, en este caso, aunque la autora no llegó nunca a celebrarlo, culminar con el reconocimiento del dogma, el 8 de diciembre de $1854^{22}$.

Pero, ¿dónde termina y dónde comienza la obligación de confesar su plagio? María Gertrudis copió la glosa del Viernes de Pasión, sin embargo, la combinó con nuevos elementos litúrgicos, dando valor y fuerza a esa prosa ajena; no vaciló a la hora de firmar su creación aunque, probablemente, no quiso poner fecha a su publicación por no «interferir» con la del Año Cristiano, siendo su composición sin duda cercana a esta publicación religiosa.

Hecho curioso, o simplemente descuido histórico, a lo largo de las ediciones de este texto nunca se mencionó el hurto, quizás, porque nadie hasta hoy se había percatado o, quizás, porque al fin y al cabo no tenía tanta importancia. ¿Cuántos autores famosos deben su fortuna a oscuros escritores que nunca se molestaron en mencionarles? Los autores griegos se plagiaron los unos a los otros, fue costumbre de todos los países y de todos los tiempos, y más aún cuando el texto era de carácter religioso: a lo largo de la historia, los padres de la Iglesia no hicieron más que sacar ideas de los escritos de los demás, algo muy habitual en todas las religiones ${ }^{23}$. Según la definición de plagio de Marmontel, los pedantes tenían la vanidad de mostrar erudición al descubrir el hurto literario y los envidiosos el placer de pensar humillar a los grandes ${ }^{24}$. Por

\footnotetext{
20 Ibidem, XII, fol. 679.

21 Ibidem, Suppl. IV. de las tablas de Panckoucke, fols. 388-390.

22 Ibidem, VIII, fol. 567.

23 Ibidem, V, fol. 829.

24 Ibidem, VIII, fol. 567.
} 
tanto, ¿ella se consideró una copista servil y prefirió callar su superchería, o no lo confesó porque no pensaba serlo? A mi parecer, dio a ese texto en prosa su verdadera dimensión: por su disposición, exaltó una idea que no era propia, es cierto, pero ofreciéndole, sin embargo, una nueva existencia ${ }^{25}$. Sin esa intrusión literaria de Sor María Gertrudis de la Cruz Hore, sin ese maquiavelismo retórico, este erudito e interesante texto se hubiese quedado en el olvido para siempre. Es cierto que su creación tuviera mayor valor y más modestia si sólo hubiese sido escrito por ella, sin embargo, si se apropió la glosa era de suponer que este discurso le conmovió, le pareció muy ajustado para alabar a la Virgen María y conforme a su pensamiento. ¿Para que dejar de expresar lo que uno piensa, sólo porque otros ya lo han pensado? En palabras de Marmontel, el verdadero plagio, era el que el público no aprobaba, el que no producía utilidad alguna, ni placer nuevo. El campo de la invención tiene sus límites y lo importante para el lector reside en el punto de encuentro con un tema entrañable. Por tanto, y pese al descubrimiento de su maniobra literaria, tras estudiar detenidamente la composición en su totalidad, así como consultar varios números del Año Cristiano publicados en los siglos XVIII y XIX, me parecía que Sor Gertrudis había alentado el género, al menos en cuanto a la estructura de la composición del «Stabat», al reunir poemas sagrados con la llamada literatura del sentimiento religioso.

Su originalidad, pese a la imitación servil en la glosa, se debía a un acto de fusión entre la liturgia adoptada por la publicación el Año Cristiano para el Viernes de Pasión, según el Evangelio, y el uso del Misal Latino Romano para la Fiesta de la Virgen de los Siete Dolores celebrada el 15 de septiembre ${ }^{26}$. María Gertrudis recuperaba algo de la literatura medieval en la que la poesía era el elemento fundamental de la creación, a la vez que estrechaba su relación con la música y el canto gregoriano, el elemento monástico por excelencia en el desarrollo de la poesía sagrada, de los himnos y de las secuencias. Acababa de entrometerse en el campo de la retórica intangible, incorporando sus plegarias a la música sacra, estrechando dos tiempos litúrgicos habitualmente distantes.

\section{La organización del «Sabat»: entre Año Cristiano y Misal Romano}

Descubrimos más detenidamente la disposición y estructura de esta composición entre traducción y plagio, una combinación de literatura moral con alto grado de religiosidad, un juego dramático por medio de la liturgia y de los misterios latinos hábilmente integrado por esta gaditana.

25 Ibidem, Suppl. IV. de las tablas de Panckoucke, fol. 388.

${ }^{26}$ Liber Usualis Missae et Officii pro dominicis et Festis cum Cantu Gregoriano ex editiones Vaticana Adamussim Excerpto et rhytmicis signis in subsidium cantorum a solesmensibus monachis, Romae 1936.

Hispania Sacra, LVIII

118, julio-diciembre 2006, 579-607, ISSN: 0018-215-X 


\subsection{El «Himno a Víspera»}

Primero, Sor Gertrudis eligió traducir el poema latín llamado «Himno a Víspera», o sea, parte del oficio divino o del breviario (hoy día llamado liturgia de las Horas). Éste se cantaba o se recitaba por la tarde a la puesta del sol o después de cenar y, según el ritual eclesiástico, se distinguía las primeras vísperas de las segundas. Era de suponer que se trataban de las primeras, las que se cantaban la víspera y abrían la fiesta, dado que las segundas las terminaban. Este oficio fue instaurado en la Iglesia desde la Antigüedad. Según la tradición, se recitaban varios salmos y se entremezclaban con rezos. Estructuradas del mismo modo que laudes (consistía en tres o cuatro salmos y en una lectura seguida de un cántico), las vísperas fueron instituidas para honrar la memoria de la sepultura de Jesucristo o su bajada de la Cruz y solían terminarse por la recitación de la oración dominical. Adoptando el canon, Sor Gertrudis empezó por el Himno, abrió, protegida por la oscuridad de la noche, su defensa y elogio de la Virgen María recordando la Pasión de Cristo. No eligió el himno más utilizado en la oración de la Iglesia, el Magnificat o cántico a María (Lc. 1, 47-55), en su búsqueda espiritual de la Virgen sin pecado concebida, sino señaló, naturalmente, el Centro de la Salvación y recordó al Hijo cuando cargó con la cruz (Jn. 19,17), a Jesús clavado en la cruz (Lc. 23, 33) y cuando murió en la cruz (Mc. $15,37)$ en presencia de su madre ${ }^{27}$.

\subsection{La Misa en honor de los siete dolores de la Virgen}

Al terminar la traducción de su primer cántico, siguió el Evangelio de Lucas, el que recogía mayor información sobre la Virgen ${ }^{28}$, aludió a la profecía de Simeón, hombre justo y temeroso de Dios, que profetizó lo que le sucediera cuando, cuarenta días después del nacimiento de Jesús, queriendo satisfacer a los preceptos de la Ley, la Virgen se fue al templo para presentarle a su hijo (Lc. 2, 25-35). En el Misal Romano aparece como la primera oración del Viernes de Pasión tras el Introito Joann 19, 2529 así como durante los Dolores gloriosos de la Santísima Virgen celebrados el 15 de septiembre. La oración en latín del profeta Simeón formaba parte de la «Sequentia Stabat Mater»en música, tal y

27 Para escribir este artículo hice ampliamente uso de la Biblia didáctica de la Casa de la Biblia, ed. Sígueme, Madrid, 1996, (816 pp.) así como del libro de Santiago MARTín, El evangelio secreto de la Virgen María, Barcelona, 2004 (265 pp.). Agradezco a Sebastián Rosado y Joaquina Sánchez por ofrecerme su Biblia.

28 La Anunciación del ángel Gabriel a María (Lc. 1, 27-38), la visita a Isabel, madre de Juan el Bautista y pariente, el himno de María, el Magníficat (Lc. 39-56).

29 PP. P. RAmbla y J. ARRUfat, Misal romano seráfico latino español o sea misal de las órdenes franciscanas, Barcelona, 1930, p. 262. 
como se practicaba antes del Concilio Vaticano II, en tiempo de Pasión ${ }^{30}$. Esta oración se encontraba también en la publicación de 1791 del Año Cristiano con algunas, aunque escasas, variaciones en la traducción, además de otra oración de la que Sor Gertrudis decidió prescindir ${ }^{31}$.

\subsection{La Epístola es del capítulo XIII del libro de Judit}

Antes de introducir las Reflexiones del Año Cristiano, María Gertrudis tradujo la «Epístola del capítulo XIII del libro de Judit», extraído de uno de los siete libros deuterocanónicos del Antiguo Testamento, mientras que la elección más habitual para este período de luto, en el que todas las oraciones de la Iglesia indicaban dolor y aflicción, era la profecía de Jeremías, figura al parecer la más propia, tanto de los dolores de Jesucristo en su Pasión, como de las desdichas causadas por los pecados cometidos ${ }^{32}$.

La elección del capítulo XIII, de este libro compuesto por XV, narraba el momento en el que Judit se disponía, tras la embriaguez de Holofernes, a cortarle la cabeza. Ella fue el instrumento de Dios: sedujo y, luego asesinó al general asirio. Holofernes era la síntesis de las potencias del Mal mientras que Judit, la judía, era la mujer a través de la que llegaba la salvación. La figura de Judit floreció en el arte europeo a partir del Renacimiento. Era de sobra conocido el cuadro de Carlo Saraceni (h. 1612) en el que la heroína enseñaba su cabeza cortada o, quizás, más representativo de la elección de la poetisa, el de Sandro Botticelli titulado «Judit regresando de Betulia», cuya sorprendente delicadeza rompía con la armonía mujeril de esta fémina a la espada asesina.

María Gertrudis eligió una de las cuatro Narraciones didácticas entradas en el canon cristiano sólo a finales del siglo I y en absoluto el Libro proféticos de Jeremías como en el Año Cristiano ${ }^{33}$. La elección de Judit, alzando la figura femenina de esta joven viuda independiente y muy religiosa, totalmente entregada al Dios de Israel como intercesora en esta gran victoria, reflejaba su firme voluntad: destacar la importancia del referente femenino en este camino hacia Dios, apartándose de las lamentaciones de Jeremías y adoptando el oficio musi-

30 Después del Concilio Vaticano II se suprimió el viernes de Dolores, una semana antes de Semana Santa, y desde hace poco de nuevo se practica para la Fiesta de los Siete Dolores, o las vísperas para la Fiesta después del domingo de Pasión, según el Misal Latíno del Vaticano. Liber Usualis Missae..., p. 1422.

31 Año Cristiano..., IIII, 110.

32 Ibidem, 1-2.

${ }^{33}$ La autenticidad de esta Narración fue muy contestada a lo largo de la historia. San Agustín en el libro dos, capítulo ocho, de la Doctrina cristiana lo recibió como canon. Finalmente, fue incluido en el canon bíblico de la Iglesia católica en 1546 zanjando así doce siglos de polémica en relación con su inclusión en la Biblia. Encyclopédie, IX, fol. 4 y XVI, fol. 365. Supl., III, fol. 445. 
cal en vigor para la Fiesta de los Siete Dolores del 15 de septiembre, es decir después de la Cuaresma y, por tanto, a mi parecer, con cierto toque de alegría por la Resurrección del Salvador, una plegaria llena de Esperanza, aunque sin alleluias.

Si seguimos la lectura del Misal Romano, al igual que en la composición de Sor Gertrudis, aparecía el apartado Lectio libri Judiht $13^{34}$. Su elección, traducir la Epístola del capítulo XIII del libro de Judit, se apartaba claramente de la estructura litúrgica habitual en la época. Apostó por una fusión literaria y musical profundamente femenina. No me cabía la menor duda al considerar la elección del autor del Año Cristiano, capítulo diecisiete del profeta Jeremías según el Evangelio, del que no quedaba rastro alguno en la creación de Sor Gertrudis $^{35}$. Ella prefirió introducir ese Oremus recogido en el Misal Romano justo antes del canto Doloroso et lacrimabilis es Virgo Maria stans juxta crucem... ${ }^{36}$, dando una clara dirección inmaculista a su creación, combinando las últimas directrices cismontanas con la liturgia imperante y su vertiente musical, una manera sin duda más personal de acercarse a Dios y a su Madre. La música ocupaba un lugar importante en el ritual religioso, favorecía el acercamiento a lo sobrenatural y María Gertrudis, muy aficionada a la música, lo sabía bien ${ }^{37}$. Si la función de la música llamada religiosa consistía en establecer vínculos especiales con los fieles, aunque en este caso sin sonido, que sepamos, pero con el ritmo, su relación con la divinidad trascendía el Verbo e invitaba a la fusión. Sin duda influenciada por la literatura medieval en la que las virtudes de la música y de la retórica unían ciencia del lenguaje y creación poética, su concepción litúrgica meditativa tendía al análisis e unificaba el oficio en una sola dirección substancialmente femenina. La sólida formación musical de Sor Gertrudis me parecía el elemento a tener en cuenta a la hora de estudiar este texto impregnado de su experiencia tanto lírica como religiosa. Tampoco me parecía improcedente creer que las monjas representaron en la iglesia de Santa María dicha plegaría en alabanza a la Virgen María, con o sin presencia de público gaditano, durante uno o quizás varios días ${ }^{38}$.

34 Liber Usualis..., pp. 1631-1632.

35 Año Cristiano..., III, 111.

36 Liber Usualis Missae ..., p. 1633.

37 «De los Gaditanos de que hemos escrito y que han sido Profesores o aficionados a los Nobles Artes, o a la Música: María Gertrudis Hore = Música», N. M. DE CAMBIASO, Op. cit., III, pp. 177-178.

38 Representar el «Stabat»en el Altar Mayor de la iglesia conventual, un proyecto en colaboración con las monjas de Santa María, la ayuda de Sonia Jiménez Romero (Sor Gertrudis) y Delicia Cebrián López (Narradora) de la Universidad Complutense de Madrid que esperamos llevar a bien a finales de septiembre de 2006 con la ayuda de la Delegación de Cultura de Cádiz. 


\subsection{Las «Reflexiones»}

Sor María de la Cruz abandonó la traducción del Misal por un momento. Cogió el Año Cristiano y copió las «Reflexiones» y «Meditaciones «como si fuese ella la autora. Hizo suyas la ocho páginas de esta literatura polémica llamada literatura del sentimiento religioso, cuyo tema principal era la relación del ser humano con Dios a través del rezo y de la expresión de un «yo» siempre confiado y entregado. El declive de esta literatura fue uno de los signos de la decadencia del movimiento espiritual en el mundo de los seglares. Por tanto, su presencia en el repertorio español a finales del Setecientos revelaba, o al menos eso pretendía, una fe profunda, latente en esta singular poetisa gaditana. Sor María de la Cruz manifestaba al público lector su originalidad hacia el Creador y su Madre, en esta época descalificada en numerosas ocasiones por ser culpable de sentimientos profanos y menosprecio a la Iglesia. No obstante, durante el reinado de Felipe II, a diferencia de Francia, la realeza española se apoderó de los decretos del Concilio de Trento y encabezó la Contrarreforma católica militante, otorgándose privilegios antes reservados a los prelados: la elección de los Obispos (nombrados por el Rey), los derechos de patronato (prerrogativa real), y la reforma de las órdenes militares y religiosas, por citar sólo algunos ${ }^{39}$.

A mi parecer, la realización de esta devota publicación de éxito podría corresponder con la necesidad de cumplir con un acto oficial y, en especial para la fiesta de la Concepción (advocación del monasterio) o, tal vez, fuera una petición por parte de algún eclesiástico la que invitó a la Hija del Sol a crear este texto devoto en perfecta adecuación con el canon. Probablemente, no conozcamos nunca la razón de esta creación.

Sin embargo, decidida a feminizar «sus» Reflexiones, al no elegir al profeta Jeremías, y con voluntad de pulir el género, María Gertrudis empezó por una frase en latín tal y como lo exigía el precepto: «Non pepercisti animøe tuœ propter angustias et tribulationem generis tui, sed subvenisti ruince ante conspectum Dei nostri. Nada puede aplicarse mejor a la santísima Virgen...». Mientras que en la publicación del Año Cristiano no aparecía frase en latín alguna, como lo exigía el precepto, sino una en español relacionada con el profeta Jeremías: «Todos los que te abandonan, serán confundidos. Del Señor es de quien habla el Profeta, y ninguna cosa puede aplicarse mejor a la santísima Virgen...» ${ }^{40}$.

A través de alusiones bíblicas y contemporáneas, inspirada por los Evangelios con parecer «espontáneo» y «patético», al igual que en las Meditacio-

39 Ignacio Fernández TERriCABrias, Philippe II et la Contre-Réforme. L'Église espagnole à l'heure du concile de Trente, París, 2001 (764 pp.).

40 Año Cristiano..., III (1791), 112. 
nes de Luís de Granada, María Gertrudis hizo suyas las reflexiones y los comentarios eruditos (San Agustín, el Canciller de la Sorbona...) de este autor de finales del Setecientos. El texto copiado por la Madre Cruz invocaba a los Padres de la Iglesia, alegaba la veneración a María para no perderse. Las expresiones patéticas y el carácter «espontáneo» de esta copia, en perfecta adecuación con el género literario, se traducían por la acumulación de signos de admiración:

¿Qué expresiones tan nobles y tan patéticas en sus escritos! ¡Qué términos tan enérgicos y tan expresivos! Tú, Virgen santa, eres después de Jesucristo la única esperanza de los pecadores, dice San Agustín ${ }^{41}$.

Al estilo del exemplum medieval, unido a la predicación y a la conversión, el autor buscaba la retórica de la persuasión, se dirigía directamente a la Virgen María citando a San Agustín (354-430). Luego, mencionó a San Jerónimo (c. 345-419), cuya obra más importante fue la Vulgata, traducción de la Biblia en latín. Para atestar del papel fundamental de intercesora de la Madre, citó a San Anselmo (c. 1033-1109), quien en su búsqueda de la fe concluyó su obra con el Proslogium (1078), creación que en el siglo XVIII llegó a conocerse como el argumento ontológico de la existencia de Dios.

En el contexto de estas reflexiones mariales, Sor Gertrudis parecía querer desvelar sus conocimientos sobre la polémica, aludiendo al Canciller de la Universidad de París, resaltando su apertura religiosa y literaria hacia el mundo:

No temas excederte, decía el sabio Canciller de la universidad de París, mientras pongas a María debajo de Dios, y en la clase de las criaturas: no temas llevar demasiado altas sus alabanzas, o tus pensamientos: sabe solamente, lo que nadie ignora, que todos los bienes que tiene vienen de Dios, y que no es rica sino de los bienes de su Hijo: esta verdad supuesta, no temas otra cosa al hablar de María, continúa el mismo Doctor, sino decir demasiado poco: por grande, por sublime que parezca lo que se dice, acuérdate que es de la Madre de Dios de quien se habla, y así no temas decir cuanto quisieres. El Evangelista sólo dice de María que es Madre de Jesús: y diciendo esto, lo ha dicho todo $^{42}$.

Estas palabras no fueron suyas pero, al igual que el autor, la poetisa no parecía querer entrar en la polémica, sino recordar las dos acepciones comunes de sobra conocidas para hablar de María, como «Madre de Dios» y «Madre de Jesús». El juicio emitido por esta revista ya publicada, no ofrecía peligro alguno a la hora de publicar su propia creación.

\footnotetext{
41 Año Cristiano (1863), 282-283.

42 Año Cristiano (1863), 282-283.
} 
Si seguimos el hilo de su composición, introdujo la Secuencia, la del Viernes de Pasión mientras en el Misal (p. 262) tras la Epístola, teníamos el Gradual (parte de la misa que se rezaba entre la epístola y el evangelio), el Tracto (versículos que se cantaban o rezaban antes del evangelio en la misa de ciertos días) y, finalmente, la Secuencia. Por otra parte, en el Año Cristiano (p. 114) teníamos antes de la Meditación, y sin que aparezca Secuencia alguna, el capítulo 11 del Evangelio de San Juan, un episodio totalmente ausente de la composición de Sor Gertrudis.

\subsection{El «Stabat Mater dolorosa» $\mathrm{o} \ll$ Secuencia»}

El centro de su creación se hallaba, pues, en la traducción del «Stabat Mater Dolorosa». Aquellos versos conferían el título de su composición y representaban una de las obras maestras del arte poético religioso medieval. Era un conjunto de frases acongojadas, de súplicas dolorosas dirigidas a la afligida Madre de Jesús, contemplándola al pie de la Cruz desde que le clavaron en ella hasta que expiró. Inspirándose en el capítulo 19, versículo 25 del Evangelio según San Juan, el «Stabat Mater Dolorosa» describía a María al pie de la cruz lo que le diferenciaba del «Stabat Mater Speciosa» desaparecido de los oficios y que describía a María delante de la cuna de Jesús.

Siguiendo las pautas de las poesías barrocas del sentimiento religioso, tras reflexionar en verso sobre la legitimidad de María, Sor Gertrudis retomó, como en el Año Cristiano esta vez, el versículo sacado del Evangelio de San Juan: «Estaban junto a la cruz...» ${ }^{43}$. En el Misal Romano esa oración en latín se practicaba igualmente el Viernes de Pasión y correspondía al Introitus Ad Missam, o sea al comienzo de la plegaria ${ }^{44}$.

Difícilmente, el género literario podía separarse de las creaciones musicales que le acompañaron. La secuencia era una forma de composición litúrgica monódica que se expendió entre los siglos IX y XIV. El término tenía dos acepciones: por una parte, hacía referencia a una adición al canto del oficio litúrgico (nacida en la baja Edad Media) mientras que su otra acepción era estrictamente musical y más tardía. A finales del siglo XV, el poema se cantaba sobre una melodía de coral y formaba parte integrante de la liturgia católica. Por la belleza de su métrica, su fuerza emocional, el texto invitaba a la creación musical. Por ello, acabó transformándose en un género musical en sí (Scarlatti, Haydn, Pergolesi, Schubert, Rossini, Dvorák, etc.).

43 Año Cristiano III, (1791), 313-314.

44 PP. P. RAmbla y J. ARRUFAT, Misal romano seráfico latino español o sea misal de las órdenes franciscanas, editorial de arte católico, Barcelona 1930, p. 262. 
En perfecta armonía con el canon, María Gertrudis eligió precisamente esta forma para traducir el «Stabat». Aunque la palabra «secuencia» tenga dos acepciones, una musical y otra literaria, quiso, a mi juicio, poner de relieve el carácter musical de esta composición. En su comienzo, la secuencia designaba cualquier vocalización que seguía el final de algunas frases y piezas litúrgicas. Finalmente, el alleluia, larga vocalización, engendró hacia el siglo X las secuencias y, en especial, el dicho «Stabat Mater» ${ }^{45}$.

\subsection{La «Meditación» de los dolores de la Santísima Virgen}

A continuación, Sor Gertrudis decidió servirse de la Meditación sobre los dolores de la Santísima Virgen publicada en el Año Cristiano de 1791 y organizó su supuesta alocución de forma didáctica, adoptando la misma estructura y partes de la revista, seguidos de algunas jaculatorias y propósitos. Esta posición del «yo», esencial y dinámica, era la estructura constante en la literatura de sentimiento religioso, sin embargo, no ofrecía garantía alguna sobre la sinceridad del autor...

Aunque fuese mujer culta de finales del siglo XVIII, cuando el llamado romanticismo empezaba a brotar en las creaciones literarias europeas, la ilustrada María Gertrudis Hore seguía impregnando sus conocimientos de amplios volúmenes dedicados a la literatura de sentimiento religioso, sin que estas lecturas le impidiera, sino al contrario, instaurar novedades y originalidad en su forma de hacer literatura. La influencia de los grandes maestros de la espiritualidad de la Contrarreforma ejerció su autoridad allende las fronteras de la religión: los Ejercicios espirituales de Ignacio de Loyola, las Meditaciones de Luis de Granada, o la Introducción a la vida devota de Francisco de Sales enseñaron a muchos a detenerse algo más en su propia interioridad. Sus lecturas no eran de extrañar sino comunes al círculo social en el que la poetisa se movió tanto antes como después de ser religiosa profesa. Estas obras le enseñaron, y probablemente mucho antes de vestir el velo, una forma de introspección en su propio ser.

Sor Gertrudis exaltó su pasión y sus convicciones acerca de la Concepción de María con total libertad, aunque estas palabras nunca fueran suyas:

PUNTO PRIMERO.-Considera que no sin razón llama la Iglesia a la santísima Virgen Reina de los Mártires: ninguno de estos héroes cristianos padeció un martirio más doloroso que el de esta afligida Madre. ¿Quieres tener una justa idea de los dolores de la santísima Virgen? ${ }^{46}$.

\footnotetext{
45 Enciclopedia Universalis, versión 9 (formato digital).

46 Año Cristiano (1863), 285.
} 
La proximidad y la intimidad con la que se dirigía al lector, al menos eso parecía, cumplieron con su compromiso literario de persuasión. ¿Cómo no sentirse atraído por aquella devoción? o al menos «comido» por la duda provocada por la concepción de su «supuesta» fe en Jesús. Sor Gertrudis recogió un episodio esencial del Evangelio. El tormento era el centro de la argumentación y, en este discurso plagiado por la poetisa, el dolor invadía su alma provocándole un profundo sentimiento de aflicción:

Una compasión seca y puramente especulativa muestra que se interesa uno poco en los bienes o males del que padece. Parte, divide y alivia los dolores de una persona afligida quien los siente verdaderamente. (...) ¡Qué dureza, y qué ingratitud más negra, que el ser tan poco sensibles a lo que la santísima Virgen padeció por nuestra causa! Échate en cara, y repréndete esta insensibilidad ${ }^{47}$.

A mi juicio, la fuerza de su maniobra literaria residía en su decidida propensión, la de aminorar el sentimiento de aflicción presente en la edición plagiada de 1791, al suprimir las lamentaciones de Jeremías, exclusivamente reservadas a la lectura cantadas de los llamados «llantos», para sustituirlas con valores heroicos femeninos.

Supo combinar las virtudes de la música con la retórica, una retórica del ser mujer, aunando el conocimiento del lenguaje en una poética siempre innovadora. Esta creación, al fin y al cabo, lejos de carecer de originalidad ofrecía dentro del canon una nueva relación a medio camino entre los distintos tiempos litúrgicos, el canto gregoriano y el Evangelio. Al publicar esta larga plegaria en verso y prosa María Gertrudis decidió comprometerse social e institucionalmente, dando pruebas de sus sólidos conocimientos litúrgicos, de su formación musical de calidad, así como de su perfecto dominio de la lengua latina y, pese al efecto plagio, de su capacidad de creación ante un tema de tanta trascendencia para la Iglesia Católica. El fervor andaluz para con los Dolores de la Santísima Virgen, su arraigo ante las creencias marianistas, siendo hija ilustre de Andalucía, le invitó a alabar y defender el culto a la Virgen María con vehemencia.

Ante las reticencias en reconocer el genio en las ilustradas españolas, descubría, pues, entre plagio y traducción, a esta astuta religiosa a la que nunca faltó el arrebato ni la pasión, dejando el testimonio hurtado de lo que quizás fueron sus convicciones, eso sí, siempre consciente del poder perenne de la palabra escrita, aun cuando no fuese suya.

Sor María de la Cruz Hore confirmaba, o al menos pretendía confirmar, y con arrebato, el logro de una conversión perfecta, la de una mujer rica y adula-

${ }^{47}$ Ibidem, 287.

Hispania Sacra, LVIII

118, julio-diciembre 2006, 579-607, ISSN: 0018-215-X 
da que había abandonado para siempre las futilidades del mundo exterior para consagrarse de lleno a la advocación de su monasterio. No obstante, me pregunté si esta dama de la alta sociedad gaditana, quien probó telas indias en la clausura, compró joyas, tembleques, poseía vajilla china y otros platos de moda en su celda, había realmente alcanzado ese estado de plenitud espiritual que algunos de sus escritos pretendían reflejar. Tal vez, el plagio ayude a pensar que no tenía voz propia para defender tan bien la legitimidad del culto marianista, sino sólo buena práctica de la traducción latina y, por cierto, algo de osadía literaria para confundir al lector durante algo más de dos siglos, combinando copia entusiasta con traducción sagrada, sus armas para defender, y por todo lo alto, sus aparentes convicciones.

APÉNDICES

Himno a vísperas

Glosado y traducción del mismo ${ }^{48}$

Illa semper virens Rosa

Sola nata sine spinis

Morituro Filio affinis

Stabat Mater dolorosa.

Tremebant, et caro, et ossa,

Nati in se sentiens tormenta,

Fuitque Martyr incruenta,

Juxta crucem lacrymosa.

Nil Agno vidit humilius

Iniquitatis sequacibus

Lupis tradito rapacibus,

Dum pendebat Filius.

Cujus cerneres pallentem

Vultum, cujus cor contritum,

Cujus corpus pona attritum,

Cujus animam gementem.

Juxta Filium suum patentem

Omnipotens sibi gratam
La que nació fresca rosa,

Sin espinas del pecado,

Del Hijo, que muere al lado,

Firme estaba y dolorosa.

Todo su cuerpo temblando

Por su amado se atormenta,

Y fue Mártir incruenta

Cerca de la cruz llorando.

Nada más humilde vi ya

Que aquel Cordero entregado

A tanto lobo irritado

Mientras de la cruz pendía.

Su rostro pálido vieras,

Su corazón contristado,

Su cuerpo mortificado,

Y su alma gemir oyeras.

A su Hija más querida

Colocó el Omnipotente

48 Por la R. M. D. a María Gertrudis de la Cruz y Hore, religiosa del convento de Santa María de Cádiz en Año Cristiano del R.P Juan Croisset, trad. José M. ${ }^{a}$ Díaz, 2. da Viernes de Pasión, II, 1863, pp. 278-287. 
Posuit eam desolatam,

Contristatam, et dolentem.

Animan replevit radius

Inaccessibilis, lucis,

Sed simut doloris trucis

Pertransivit gladius.

Omnia membra vidit icta,

Virginem carnem trementem,

Faciem alapis tumentem:

O quam trístis, et afflicta!

Tot inter ponas invictiva

Exoptans pro Jesu pati,

Et mori loco sui Nati,

Fuit illa benedicta.

Omipotentis ingeniti

Filium ob nostrum delictum

Aspiciebat derelictum

Mater Unigeniti.

Jesus in cruce pendebat,

Maria pendere optabat,

Que gemebat, et plorabat,

Quæ mœrebat, et dolebat.

Procera brachia cernebat

Dira rigentia tensione,

Caput obsitum punctione,

Et tremebat cum videbat.

Quot gemitus! Sed quam irriti

Apud Deum fudit Mater!

Ut tot jam levaret Pater

Nati pœnas inclyti.

Dum sic Maria doleret,

Dum Jesus sic torqueretur,

Ut mundus redimeretur:

Quis est homo, qui non fleret?

Quis esset, qui non arderet

Vehementissimo amore

Totam confectam morore,

Christi Matrem si videret?

Nostro expiando flagitio

Vidit Filium innocentem

Proprium sanguinem fundentem
Cerca del Hijo paciente

Sola, triste y dolorida.

A su alma iluminaba

Una luz maravillosa;

Pero una espada horrorosa

Con dolor la traspasaba.

Vio en sus miembros tanta herida,

Trémulo el cuerpo sagrado,

De golpes el rostro hinchado,

¡Oh qué triste y afligida!

Invencible se sostuvo

Deseando allí sufrir,

Y por su Hijo morir,

La Virgen bendita estuvo.

Del Omnipotente ingénito

Al Hijo desamparado,

Vía por nuestro pecado

La Madre del Unigénito.

Jesús de la cruz pendía, Pender de ella deseaba

María, y así lloraba,

Se angustiaba y se dolía.

Los altos brazos miraba

Con cruel rigor tirantes,

Vía las espinas punzantes,

Y cuando lo veía temblaba.

¡Cuánto ruego no escuchado

A Dios dirige la Madre,

Pidiendo consuelo al Padre

En las penas de su amado!

Viendo afligida a María,

Y viendo a Jesús penar,

Porque nos va a libertar,

¿Qué hombre no lloraría?

¿Quién habrá que no se ardiera

En vehementísimo amor,

$\mathrm{Si}$ agobiada de dolor

La Madre de Cristo viera?

Porque piadoso pagó

Nuestra deuda, al Hijo amado

En propia sangre bañado 
In tanto supplicio.

Cernens coram eo immolari

Natum, quin nuntium audiret,

Ut Abraham, qui impediret,

Quis posset non contristari?

Nostrum opus lacrymari

Sit coram Jesu patiente,

Et afflictam, pura mente,

Piam Matrem contemplari.

Potentem in hoc exilio

Habebimus Protectricem,

Si colamus Genitricem

Dolentem cum Filio.

Frontis semper refulgentis

Pulchrum videbat candorem

Immutatum in pallorem

Pro peccatis suæ Gentis.

Artubus dure distentis,

Clavis manibus confixis,

Pedibus simul transfixis,

Vidit Jesum in tormentis.

Derisum, ligatum, subditum,

Abjectum, et blasphematum,

Prius conspexerat Natum,

Et flagellis subditum.

Crucis morti adjudicatum,

Crucem humeris ferentem,

Pondere in terram cadentem,

Vidit suum dulcem Natum.

Felle, et aceto potatum,

Angustiis pressum, sitientem,

Suspiria ad Patrem mittentem,

Morientem, desolatum.

Ducem tandem vidit inclytum

Morte inimicum fugantem,

Et voce magna clamantem,

Dum emisit spiritum.

Eja Abyssus diri angoris,

Eja Martyrum Regina,

Eja Stella matutina,

Eja Mater Fons amoris.
Y en tanto suplicio vio.

Viendo a su Hijo inmolar,

Sin que como Abraham oyese

$\mathrm{Al}$ nuncio que le impidiese,

¿Quién no se ha de contristar?

Estemos siempre llorando

Mirando a Jesús paciente,

$\mathrm{Y}$ a su fiel Madre doliente

Con humildad contemplando.

En este destierro es fijo

Protectora la tendremos,

Siempre que la veneremos

Doliéndose con su Hijo.

De aquella cándida frente

Veía el hermoso esplendor

Mudado en cetro color

Por las culpas de su gente.

Todos los miembros violentos, Manos, y pies traspasados, Con duros hierros clavados, Vio a Jesús entre tormentos.

Menospreciado y atado, Blasfemado, escarnecido, Ya había visto a su querido, $\mathrm{Y}$ a azotes condenado.

Y ya a la cruz sentenciado

La vio en sus hombros traer,

Y con el peso caer

Su dulce Jesús amado.

Con vinagre y hiel mezclado

Ve que le están afligiendo,

Y que a su Padre gimiendo,

Muere ya desconsolado.

Viole en fin cuando ahuyentó

$\mathrm{Al}$ contrario con su muerte,

Y clamando con voz fuerte

El espíritu exhaló.

Ea Abismo de dolor,

De Mártires Reina bella,

Ea matutina Estrella,

Ea Madre Fuente de amor. 
Fac memorem tui mororis, Ponasque Jesus colentem, Contritum, et ponitentem, Me sentire vim doloris. Ut mihi non male indulgeam, Ut culpam puniam meam, Ut peccata semper fleam, Fac ut tecum lugeam. Me jam tot scelerum reum, Ingenti arreptum dolore, Jesus percussum amore, Fac, ut ardeat cor meum. Fac me currere post eum Ejus vestigia sequentem, Fac alacrem, et ferventem In amando Christum Deum. Jesu laudes nunquam taccam, Jesum exoptans languescam, Jesui serviens non tepescam, Ut sibi complaceam. Amén.
Haz que mi memoria atenta $\mathrm{Al}$ dulce Jesús doliente, Contristado y penitente, Siempre sus dolores sienta. Que mis pasiones no dore, Que mis culpas las castigue, Que el pecado me fatigue, Y hazme que contigo llore. Reo soy, por esta razón Con dolor arrepentido, De amor de Jesús herido, Haz que arda mi corazón. Haz que vaya caminando Sobre sus huellas ansioso, Hazme alegre y fervoroso A Cristo mi Dios amando. A Jesús sepa alabar, Deshágame por seguirle, Nunca me entibie en servirle, Y así le podré agradar. Amén.

La Misa es propia en honor de los siete dolores de la santísima Virgen, y la Oración es la siguiente:

Deus, in cujus passione, secundum Simeonis prophetiam, dulcissimam animam gloriosøe virginis et matris Marice doloris gladius pertransivit: concede propitius; ut qui transfixionem ejus et passionem venerando recolimus, gloriosis meritis et precibus omnium Sanctorum cruci fideliter astantium intercedentibus, passionis tuce effectum felicem consequamur. Qui vivis...
Ô Dios, en cuya pasión, según la profecía del venerable Simeón, fue traspasada el alma ternísima de la gloriosa Virgen María vuestra Madre con una espada de dolor: concedednos benigno, que ya que celebramos con veneración la memoria de su compasión y de sus dolores, nos aprovechemos de ella, y por los méritos e intercesión de todos los Santos que fielmente han permanecido junto a la cruz, consigamos los dichosos frutos de vuestra pasión. Vos que vivís y reináis, etc. 
La Epístola es del capítulo XIII del libro de Judit.

Benedixit te Dominus in virtute sua, quia per te ad nihilum redegit inimicos nostros. Benedicta es tu, filia, à Domino Deo excelso, proe omnibus mulieribus super terram. Benedictus Dominus, qui creavit coelum et terram; quia hodie nomen tuum ita magnificavit, ut non recedat laus tua de ore hominum, qui memores fuerint virtutis Domini in æeternum, pro quibus non pepercisti animoe tuo propter angustias et tribulationem generis tui, sed subvenisti ruino ante conspectum Dei nostri.
El Señor te bendijo comunicándote su poder, y por tu medio ha reducido nuestros enemigos a la nada. Bendita eres tú, ô hija del Señor Dios altísimo, sobre todas las mujeres de la tierra. Bendito el Señor que crió el cielo y la tierra; porque de tal manera ha engrandecido hoy tu nombre, que tus alabanzas no faltarán jamás de la boca de los hombres que se acordaren en lo sucesivo de los portentos del Señor, por amor de los cuales no temiste exponer tu vida viendo las angustias y tribulación de tu gente, sino que socorriste a la ruina que amenazaba en presencia de nuestro Dios.

\section{REFLEXIONES}

Non pepercisti animo tuœ propter angustias et tribulationem generis tui, sed subvenisti ruince ante conspectum Dei nostri. Nada puede aplicarse mejor a la santísima Virgen, de quien los santos Padres han dicho tan repetidas veces, que así como los que la aman con ternura, la honran con perseverancia, y la sirven con fidelidad, es imposible se pierdan; así los que se apartan de ella, los que abandonan su culto, los que no tienen confianza en ella, ni la profesan aquella devoción religiosa, que reina en todos los escogidos, no pueden dejar de perderse: Necesse est ut intereat. (Bonav. in Phar.). El que sirviere dignamente a la Virgen María, será justificado, y se salvará; pero el que no hiciere caso de ella, morirá en su pecado. (In Psalt.). El mismo Jesucristo, el Espíritu Santo es quien inspiró a todas estas grandes lumbreras de la Iglesia estos grandes sentimientos de devoción, de confianza, de veneración y de amor para con la santísima Virgen: el Espíritu Santo fue quien los movió a hacer tan magníficos elogios de ella. ¿Qué expresiones tan nobles y tan patéticas en sus escritos! ¿Qué términos tan enérgicos y tan expresivos! Tú, Virgen santa, eres después de Jesucristo la única esperanza de los pecadores, dice San Agustín: estamos llenos de respeto y de veneración, dice san Jerónimo, para con aquella a quien en cierto modo de- 
bemos nuestra salud. Algunas veces somos oídos más pronto, dice san Anselmo, invocando el nombre de María que el nombre de Jesús; así como suele suceder, que se obtiene antes una gracia del rey por la intercesión de la reina, que pidiendósela inmediatamente al rey. De aquí vienen todos aquellos títulos pomposos y verdaderos que la dan de mediadora, de abogada, de madre de gracia y de misericordia, de asilo y de refugio de los pecadores: de aquí que la cante muchas veces al día la Iglesia estas bellas y afectuosas palabras: Salve regina, mater misericodio, vita, dulcedo, et spes nostra, salve: Dios te salve, Reina y Madre de misericordia, Dios te salve, vida, dulzura y esperanza nuestra. Estas expresiones jamás fueron del gusto de los herejes. Su aversión a la Madre es tan antigua como su odio contra el Hijo: ninguno se apartó de la verdadera Iglesia, que no volviese las espaldas a María. La santísima Virgen no tiene otros enemigos de su culto sino los enemigos de Jesucristo. No se apartará de la verdad, decía un antiguo Padre griego, quien dijere de María todo lo que puede decirse de grande, de sublime y de magnífico; pero, por más que diga, nunca su oración igualará a la grandeza del mérito y dignidad de María. No temas excederte, decía el sabio Canciller de la universidad de París, mientras pongas a María debajo de Dios, y en la clase de las criaturas: no temas llevar demasiado altas sus alabanzas, o tus pensamientos: sabe solamente, lo que nadie ignora, que todos los bienes que tiene vienen de Dios, y que no es rica sino de los bienes de su Hijo: esta verdad supuesta, no temas otra cosa al hablar de María, continúa el mismo Doctor, sino decir demasiado poco: por grande, por sublime que parezca lo que se dice, acuérdate que es de la Madre de Dios de quien se habla, y así no temas decir cuanto quisieres. El Evangelista sólo dice de María que es Madre de Jesús: y diciendo esto, lo ha dicho todo. En efecto, ¿debe temerse decir demasiado de esta Señora, o exceder en el culto que se la da? ¿Quién no sabe que honrar a la Madre es honrar al Hijo? La devoción que se tiene con María no divide el corazón, antes bien lo une más estrechamente con Jesucristo. La confianza que tenemos en la protección de la santísima Virgen no disminuye la que debemos tener en su Hijo, antes por el contrario la aumenta. Nuestro culto, nuestra devoción, nuestra confianza y nuestro amor para con la santísima Virgen es una prueba sensible de nuestra fe en Jesucristo. Con esta intención, y animada de este espíritu la Iglesia no deja escapar ocasión alguna de honrar a la Madre de Dios. Ya sea que autorice con el mayor gusto todo lo que se dirige a aumentar la devoción de los fieles para con este refugio de los pecadores, ya sea que multiplique tanto como vemos sus fiestas: la que se celebra este día bajo el título de Nuestra señora de la Conmiseración de los dolores, y de la pasión de la santísima Virgen, nos debe ser tanto más venerable, cuanto nosotros fuimos la causa de los dolores que traspasaron su alma. 


\section{SECUENCIA}

Stabat Mater dolorosa

Juxta crucem lacrymosa, Dum pendebat Filius.

Cujus animan gementem, Contristatam et dolentem, Pertransivit gladius. $O$ quam tristis et afflicta Fuit illa benedicta Mater Unigeniti! Quce morebat, et dolebat, Pia Mater dum videbat Nati poenas inclyti. Qui est homo, qui non fleret, Christi Matrem si videret In tanto supplicio? Quis non posset contristari, Christi Matrem contemplari Dolentem cum Filio? Pro peccatis suce gentis Vidit Jesum in tormentis, Et flagellis subditum. Vidit suum dulcem Natum Moriendo, desolatum, Dum emisit spiritum. Eja Mater, fons amoris, Me sentire vim doloris Fac, ut tecum lugeam. Fac, ut ardeat cor meum In amando Christum Deum, Ut sibi complaceam. Sancta Mater, istud agas, Crucifixi fige plagas

Cordi meo valide.

Tui Nati vulnerati, Tam dignati pro me pati Ponas mecum divide. Fac me tecum pie flere, Crucifixo condolere, Donec ego vixero. Juxta crucem tecum stare,
La Madre estaba llorosa

Junto a la cruz dolorosa, De donde su Hijo colgaba. A cuya alma en tan gran pena De tristeza y dolor llena Dura espada atravesaba. ¡Ô Dios! ¡Cuán entristecida Se encontraba esta afligida Madre del Hijo mejor! ¡Y con qué melancolía Las penas de su Hijo veía! ¡Cuántas ansias! ¡Qué dolor! ¿Quién el llanto contuviera, Si a la Madre de Dios viera Puesta en tal desolación? ¿Y quién no se contristara, $\mathrm{Si}$ a la Madre contemplara Con su Hijo en tanta aflicción? Por pagar nuestro pecado Vio a Jesús atormentado Lleno de azotes sin cuento. Morir vio a su Hijo querido De consuelos destituido, Hasta dar su último aliento. Ea, Madre, de amor fuente, Pon a mi alma tan doliente Que te acompañe en tu llanto. Haz que arda mi corazón De amor de Dios, que es razón, Pues eso le agrada tanto. Haz que en mi alma estén de fijo Las llagas del Crucifijo, Porque nunca las olvide. Las penas que en ti ha causado Ver a tu Hijo tan llagado Por mí, conmigo divide. Haz que yo contigo llore, Que en mí la compasión more De Cristo mientras yo viva. Junto a la cruz consolarte, 
Et me tibi sociare

In planctu desidero.

Virgo virginum preclara,

Mihi jam non sit amara,

Fac me tecum plangere.

Fac, ut portem Christi mortem,

Passionis fac consortem

Et plagas recolere.

Fac me plagis vulnerari,

Fac me cruce inebriari,

Et cruore Filii.

Flammis ne urar succensus,

Per te, Virgo, sim defensus

In die judicii.

Christe, cum sit hinc exire,

Da per Matrem me venire

Ad palmam victorioe.

Quando corpus morietur,

Fac, ut animœe donetur

Paradisi gloria. Amén.
Y en tu llanto acompañarte Quiero, Madre compasiva. Virgen, que a todas excedes, Pues concedérmelo puedes, Haz que llore cual tú lloras: Haz que la pasión y muerte De Cristo sienta de suerte Que logre mi alma mejoras. Hazme que viva en sus llagas, Y de su sangre ebrio me hagas, Siendo su cruz mi ejercicio. No arda en llamas encendido; Por ti, ô Virgen, defendido Sea en día del juicio. Haz, Cristo, en el postrer trance, Por tu Madre que yo alcance La palma de la victoria. Haz que cuando el cuerpo muera En la celestial esfera Goce el alma de la gloria. Amén.

El Evangelio es del capiítulo XIX de san Juan.

In illo tempore: Stabant juxta crucem Jesu, Mater ejus, et soror Matris ejus Maria Cleopho, et Maria Magdalene. Cum vidisset ergo Jesus Matrem, et discipulum stantem, quem diligebat, dicit Matri suœ: Mulier, ecce filius tuus. Deinde dicit discipulo: Ecce Mater tua. Et ex illa hora accepit eam discipulusin sua.
En aquel tiempo: Estaban junto a la cruz de Jesús, su Madre, y la hermana de su Madre María Cleofé, y María Magdalena. Habiendo, pues, visto Jesús a su Madre, y al discípulo que amaba, que estaba de pie, dijo a su Madre: Mujer, he ahí tu hijo. Después dijo al discípulo: He ahí tu Madre. Y desde aquella hora la recibió el discípulo por suya. 


\section{MeditACión}

\section{De los dolores de la santísima Virgen}

PUNTO PRIMERO.-Considera que no sin razón llama la Iglesia a la santísima Virgen Reina de los Mártires: ninguno de estos héroes cristianos padeció un martirio más doloroso que el de ésta afligida Madre. ¿Quieres tener una justa idea de los dolores de la santísima Virgen? Comprende, si puedes, cual fue la ternura, la grandeza, el ardor y pureza de su amor para con su querido Hijo. Los tormentos que se padecen en el cuerpo pueden hallar alivio, y aun dulzura en las suavidades interiores que vierte Dios en una alma: se han visto Mártires que han encontrado un refrigerio y una frescura indecible en medio de los braseros, como sucedió a los tres jóvenes hebreos; pero ¿quién puede suspender y endulzar las penas y dolores del alma? El martirio del alma es un suplicio puro y sin mezcla. ¡Qué dolorosa es la herida cuando la espada llega a traspasar el alma! Pues tal fue el martirio de la santísima Virgen: Tuam ipsius animam pertransibit gladius. Sentirás el más vivo dolor, la dijo Simeón cuando presentó a su querido Hijo en el templo: los ultrajes que se harán a tu Hijo, serán para ti otros tantos puñales que se te clavarán en el pecho. Jamás madre alguna amó a su hijo en el grado que la santísima Virgen amó al Salvador: nadie ignora lo que padeció el Salvador en el discurso de su vida mortal: ¡qué humillaciones, qué pobreza y qué persecuciones! Y durante su pasión, ¡qué dolores, qué oprobios! Concibe lo que padecería la santísima Virgen, que fue testigo de todo lo que padeció su querido Hijo. Jamás hubo martirio más largo: los treinta y tres años de vida del Salvador fueron la medida de la duración del martirio de su divina Madre. Sus penas se anticiparon a la misma vida del Salvador. ¡Qué no debió sufrir la santísima Virgen viéndose a punto de parir en Belén, desechada de todos sus moradores, reducida a refugiarse en un establo, sin socorro y sin otro alivio para un niño Dios, que el aliento y el vaho de dos viles animales, y un puñado de paja! Comprende lo que padecería en esta ocasión la más tierna, la más apasionada de las madres, tanto en su persona, como en la de su querido Hijo. Represéntate sus sobresaltos cuando supo el cruel, el impío designio que tenía Herodes de hacerle morir; ¿qué no tuvo que sufrir en su viaje y en su mansión en Egipto? ¿Estuvo más tranquila, o a lo menos fue más feliz, según el mundo, en Nazaret?

¡Qué santas inquietudes en la continúa necesidad de todas las cosas a que la reducía su estado pobre y oscuro! ¡Con qué pena no estuvo los tres días que Jesucristo se quedó en Jerusalén! Pero ¿qué no tuvo que sufrir viendo la ingratitud con que los judíos pagaban los beneficios de su querido Hijo, y sabiendo hasta qué grado llevaban su odio y su envidia los escribas y fariseos? Sería necesario conocer la perfección del corazón de María para comprender lo que padeció a vista de los tratamientos que le hacían a su divino Hijo. 
PUNTO SEGUNDO.-Considera lo que la santísima Virgen padeció, particularmente durante la pasión y en la muerte del Salvador. Se ha mirado siempre como un exceso de inhumanidad, y como el más cruel de todos los suplicios, obligar a los hijos a ser testigos de los tormentos que se han hecho sufrir a sus padres, y estar presentes a su muerte. Comprendamos, pues, qué exceso de dolor, y qué aflicción tan mortal sería para la santísima Virgen el saber la indignidad, los ultrajes y la crueldad con que el Salvador fue llevado por la ciudad de Jerusalén, el sacrílego desprecio con que fue tratado en casa de los pontífices, en la de Pilatos, en la de Herodes, y en todos aquellos impíos tribunales. No la consideres simplemente padeciendo como la más tierna de todas las madres, mírala como a una tierna Madre que sabe que ese Hijo tan amable, a quien tratan con la mayor infamia, es el único y verdadero Dios. Cuando lo vio azotar, ¿qué golpe de azote caería sobre el Hijo, que no descargase sobre el corazón y el alma de la Madre? No teniendo ya figura de hombre, lo ponen a la vista de aquel pueblo, para ver si un espectáculo tan lastimoso le movía a compasión; y aquel pueblo, el horror y la execración del género humano, como si fuera una bestia feroz, se muestra más sediento de su sangre, y clama que se le crucifique. ¿Qué impresión haría en el corazón de esta Madre desconsolada este triste objeto! ¡Qué puñaladas no serían para su corazón aquellos bárbaros gritos! Sin embargo, no basta en los designios del Padre eterno el que la Virgen consienta al sangriento sacrificio de su querido Hijo: es menester que esté presente a él, que lo vea con sus propios ojos sin fuerzas y sin sangre caer bajo el peso de su cruz; es menester que oiga todos los golpes del martillo que se den sobre los clavos que taladran sus pies y sus manos; es menester, en fin, que lo vea levantado sobre esta cruz, ultrajado sobre esta cruz, y expirar finalmente sobre esta cruz entre los más crueles y más agudos dolores.

¿Qué herida, qué tormento y qué dolor hubo en Jesucristo, que María no lo padeciese en su alma? Sin uno de los más grandes milagros, ¿no debía la Madre expirar antes que el Hijo? ¿Podía, a lo menos, sobrevivirle? ¿Se vio jamás martirio más cruel que el que padeció por nuestro amor la santísima Virgen?

¿Qué título más justo y más bien adquirido que el de Reina de los Mártires con que la saluda la Iglesia? Pero acordémonos que padeció por nuestro amor, y por el deseo de nuestra salvación, con tanta resignación, en silencio y sin quejarse.

¡Qué sentimientos de amor, de ternura, de veneración y de reconocimiento no debemos tener para con esta Madre de Dios, que se precia también, digámoslo así, de ser nuestra Madre!

Señor, por la intercesión de la santísima Virgen os pido me deis estos piadosos y religiosos sentimientos: dignaos recibir y confirmar para siempre el sacrificio que hago de mí mismo a vuestra santísima Madre. 
JACULATORIAS.- Madre, fuente del amor, hazme sentir el dolor de que estuvo penetrada tu alma, para que junte mis lágrimas con las tuyas. (La Iglesia).

Haz, Madre mía muy amada, que yo junte mis sollozos con los tuyos, y que el resto de mi vida yo contigo comparta los dolores que padeciste al pie de la cruz de mi Salvador. (Ibidem).

\section{PROPÓSITOS}

1. Una compasión seca y puramente especulativa muestra que se interesa uno poco en los bienes o males del que padece. Parte, divide y alivia los dolores de una persona afligida quien los siente verdaderamente. Si el Salvador padece y muere por nuestra salud, el mismo motivo empeña a la santísima Virgen a padecer un tan largo y tan cruel martirio: ¡qué dureza, y qué ingratitud más negra, que el ser tan poco sensibles a lo que la santísima Virgen padeció por nuestra causa! Échate en cara, y repréndete esta insensibilidad. ¡Ah Señora! ¿Quién piensa en honrar, y en agradecer lo que padeciste por nosotros? ¡Cuántas gentes mueren sin haber pensado jamás en ello! Repara este irreligioso olvido, mostrándote desde hoy en ser mucho más celoso en honrar con toda suerte de ejercicios de devoción esta fiesta: celébrala confesando y comulgando con esta intención, y ten una devoción particular a la Virgen santísima bajo el título de Nuestra Señora de los Dolores.

2. Es un ejercicio de devoción muy religioso rezar todos los viernes del año, y todos los días de esta octava, es decir hasta el Viernes Santo, el himno Stabat Mater dolorosa. Propón hacerlo desde hoy sin falta: venera particularmente los misterios que llaman dolorosos, de esta santa Reina de los Mártires: contempla estos misterios todos los viernes al rezar el Rosario. Estos misterios dolorosos son: La agonía de Nuestro Señor cuando oró en el huerto, sus azotes, la corona de espinas, cuando llevó a cuestas el pesado madero de la cruz, su crucifixión y muerte: medita un misterio a cada diez del Rosario: entra en la cofradía o esclavitud de Nuestra Señora de los Dolores: la Iglesia autoriza estas devociones. Por mucho que hagamos, nunca haremos demasiado para honrar a la santísima Virgen, y merecer su protección. 